\title{
Conceptualizing Bilingual Education Programs through CLIL and Genre-Based Approach: An Indonesian Context
}

\author{
Yogi Saputra Mahmud
}

President University, Indonesia

Correspondence: Yogi Saputra Mahmud, President University; Indonesia. e-mail: yogi.saputra@president.ac.id

Submitted: March 31, 2020

DOI: $10.29408 /$ veles.v4i1.2005

\author{
Revised: April 16, $2020 \quad$ Accepted: April 24, 2020
}

URL: http://dx.doi.org/10.29408/veles.v4i1.2005

\begin{abstract}
The implementation of bilingual education programs in the Indonesian secondary school context has experienced considerable changes in the last decade. In this case, the enactment of the International Standards School (ISS) program that propelled the students to experience bilingual education programs at schools was discontinued by the government in 2015. Consequently, the discontinuation of the ISS program leads to the scarcity of studies in examining the progress and effectiveness of bilingual education programs in Indonesia. At the same time, the phenomenon of private schools that offer bilingual programs has been significantly more popular after the ISS program was abolished. However, there is a lack of established instruction on how to implement bilingual programs in such schools. Therefore, this paper aims to conceptualize the implementation of bilingual education programs through the implementation of Content and Language Integrated Learning (CLIL) and Genre-Based Approach (GBA). Drawing on the relevant literature, this paper examines a new perspective in bilingual education programs by considering the suitability between CLIL and genre theory in the Indonesian secondary school context. Further, this paper also provides a unit of work/syllabus sample that incorporates both CLIL and GBA. Ultimately, future implications in responding to the enactment of bilingual education programs in Indonesia are also discussed.
\end{abstract}

Keywords: CLIL. Genre-based approach, bilingual education, Indonesia

\section{Introduction}

In the last decade, the application of bilingual education program has been considerably changed in the context of Indonesian secondary schools. In this case, the revolutionary change was initially marked by the implementation of the International Standards School (ISS) in 1339 schools in Indonesia (see Education Sector Analytical and Capacity Development Partnership, 2013). Although it had been discussed since 2000, the ISS program was just implemented in 2009 through the regulation issued by the Ministry of Education No. 78/2009 (Dharmaningtias, 2013; Yuliantoro, 2016). The program, however, did not last for a long time as it was abolished by the 
Constitutional Court of Indonesia after six years of the pilot program due to several reasons, including the lack of capacities to use English as a medium of instruction, the inability to meet the international accreditation, the students' low socioeconomic status, the high demand to adopt international curriculum and the lack of qualified teachers (Education Sector Analytical and Capacity Development Partnership, 2013). Therefore, the pioneering schools were no longer able to conduct the ISS program.

The discontinuation of the ISS program leads to the scarcity of studies examining the progress and effectiveness of bilingual education in Indonesia. Consequently, this paper aims to conceptualize the integration of Content Language Integrated Learning (CLIL) and Genre-Based Approach (GBA) to implement a bilingual education program in Indonesia. The discussion in this paper is started by outlining the fundamental concepts of both CLIL and GBA. In this paper, it is argued that both learning approaches are highly relevant to be implemented in Indonesia. In addition, this paper also provides a unit of work to illustrate the practice of integrating both CLIL and GBA in Senior High School Context in Indonesia. The unit of work focuses on displaying a lesson plan for a Biology lesson for Grade 10 students in Indonesia with the topic of environmental change and water recycling practice.

\section{CLIL: A Dual-focused Learning Concept}

As a dual-focused learning concept, Content and Language Integrated Learning (CLIL) was adopted in the mid-1990s as an umbrella term for bilingual education in the European continent (Coyle, 2007). This learning concept was developed to fulfill the collective needs of the European countries in naming the bilingual education program that is different from the immersion program developed in Canada (Coyle, 2007). In this case, the term CLIL has been interpreted in various ways by different scholars in the literature. For instance, Marsh (2002, as cited in Coyle, 2007, p. 545) defines it as "any activity in which a foreign language is used as a tool in the learning of a non-language subject in which both language and the subject have a joint role." Regarding this, the emphasis lies within the collective roles between language and subject during the learning process of a non-language subject, including chemistry, biology, etc.

However, the consistent and constant rationale of CLIL lies within its focus on the two dimensions (content and language dimensions). This type of bilingual education program is considered as an approach with the integrated dual-focused concepts, in which the learners at the primary, secondary, or tertiary level experience both content and language teaching and learning processes through an additional language as the medium of instruction (Bentley, 2010; Coyle et al., 2010; Christiane Dalton-Puffer, 2011; Ioannou-Georgiou, 2012; Mehisto et al., 2008). Based on its definition, it can be argued that CLIL is different from other approaches due to its integrated aims to develop both towards the language learning syllabus, as well as a subject curriculum (Ioannou-Georgiou, 2012). Unlike general English lessons, CLIL teachers select the specific learning content for the students, as well as particular language elements needed by the students to enable them to convey their ideas or to discuss the content being learned (see also Harmer, 2015, p. 8). 
As stated earlier, CLIL has been developed due to the needs of European countries in establishing the common ground for the bilingual education program in the regions. In this case, CLIL is conceptualized differently from the immersion program established in Canada due to several underlying differences. Among other researchers who outlined the differences between CLIL and the immersion program, Lasagabaster and Sierra (2009; see also Dalton-Puffer, 2011) provided an evident distinction between the two programs that can be analyzed in Table 1:

Table 1. The differences between CLIL and immersion program

\begin{tabular}{lll}
\hline Aspects & CLIL & Immersion program \\
\hline Language of instruction & A foreign language & A primary language \\
Teachers & Non-native speakers & Native speakers \\
Starting age & Secondary education & Primary education \\
Teaching materials & Different from materials used in & Similar to materials used in \\
& English-speaking countries & English-speaking countries \\
Language objective & Lower than native-like & Native-like proficiency \\
& proficiency & \\
\hline
\end{tabular}

As identified in the table above, there are some apparent differences between CLIL and the immersion program. In this case, it can be argued that CLIL is considered more relevant to be implemented in the Indonesian setting due to its characteristics. In terms of the language of instruction, CLIL utilized a language that is only used by the students in a formal setting such as in the classroom (Lasagabaster \& Sierra, 2009). In the case of international standards school in Indonesia, English as a foreign language is used as the language instruction in the classroom. Furthermore, non-native speakers of the language of instruction who are content-experts are likely to teach CLIL subjects in the classroom, while immersion programs are likely to involve nativespeakers of the language of instruction in the classroom (Lasagabaster \& Sierra, 2009). In Indonesia, non-native speakers of English usually teach content subjects without requiring English native speakers to teach in the classroom. Therefore, CLIL is considered more applicable in the Indonesian setting. In terms of the teaching materials, CLIL program utilizes the materials that are different from what is usually used in English-speaking countries (Lasagabaster \& Sierra, 2009). This is due to the fact that the learning objectives in CLIL aim to enable students to achieve lower than native-like proficiency of the language of instruction (Lasagabaster \& Sierra, 2009). Consequently, the teaching materials should also be adapted to the students' proficiency level. CLIL program normally starts when the students acquired basic literacy skills in their first language in primary education (Lasagabaster \& Sierra, 2009). This becomes the justification of the unit of work that will be displayed in the current study.

Despite its suitability with the Indonesian context, some researchers warn the practitioners related to the possible strengths and weaknesses of CLIL. Regarding this, Coyle (2007) argues that the strengths of CLIL lie within its focus on "integrating content and language learning in varied, 
dynamic, and relevant learning environments built on both 'bottom-up' initiatives as well as 'topdown' policy" ( $\mathrm{p} .546)$. Consequently, it is considered pertinent to implement CLIL program in either nationwide-scale or local settings such as in particular schools. Nevertheless, she also warns the practitioners regarding the potential weakness of CLIL since the learning concept is interpreted flexibly, it should be incorporated in "a robust contextualized framework with clear aims and projected outcomes" (Coyle, 2007, p. 546). This paper, therefore, attempts to provide new insight into CLIL implementation by embedding the concept with Genre-Based Approach (GBA) as a learning approach that has been implemented thoroughly in the Indonesian curriculum. The discussion of GBA will be explored further in the next section.

\section{Genre Pedagogy: An Integrated Approach}

Genre theory gained its popularity within a research project during the era of Sydney School on the semantic components of language inspired by Halliday's Systemic Functional Linguistics (Lorenzo, 2013; Rose \& Martin, 2012). In this case, the project conceptualised the notion of genre is as a "staged goal-oriented social practices" (Rose \& Martin, 2012, p. 1).

Morton (2010): "the main objective of this pedagogy is to make explicit the stages and linguistic features of key school genres and guide students in the production of these important text types. In order to achieve its social purpose, different genres require specific schematic structures, linguistic features, as well as discourse organisation (Rose, 2016, as cited in Lo \& Jeong, 2018). For instance, people require different language resources when they conduct two different activities, such as writing a letter to a school principal, as well as writing a cooking recipe. Consequently, the term 'genre pedagogy' is also closely intertwined with the notion of 'text types' , including descriptive, recount, report, narrative, procedure, etc. In addition, genre pedagogy primarily aims to make explicit the linguistic features and schematic structures, as well as to enact as a guide for the students to produce the school genres/text types in certain learning context (Morton, 2010).

In terms of pedagogical practice in the classroom, genre pedagogy is also closely related to the dimension of scaffolding through the implementation of Teaching and Learning Cycles that is initially proposed by genre-based theorists in 1990s and the early 2000s. Throughout its development, the Teaching and Learning Cycle is conceptualised differently by different genrebased theorists in terms of its classroom practices, including the cycle proposed by Derewianka and Jones (2012; see also Derewianka, 1990, as cited in Gibbons, 2002, 2015). Based on this theory, there are four different cycles in the Teaching and Learning Cycle, including Building Knowledge of the Field (BKoF), Modelling, Joint-Construction, and Independent Construction that will be explored further below. 


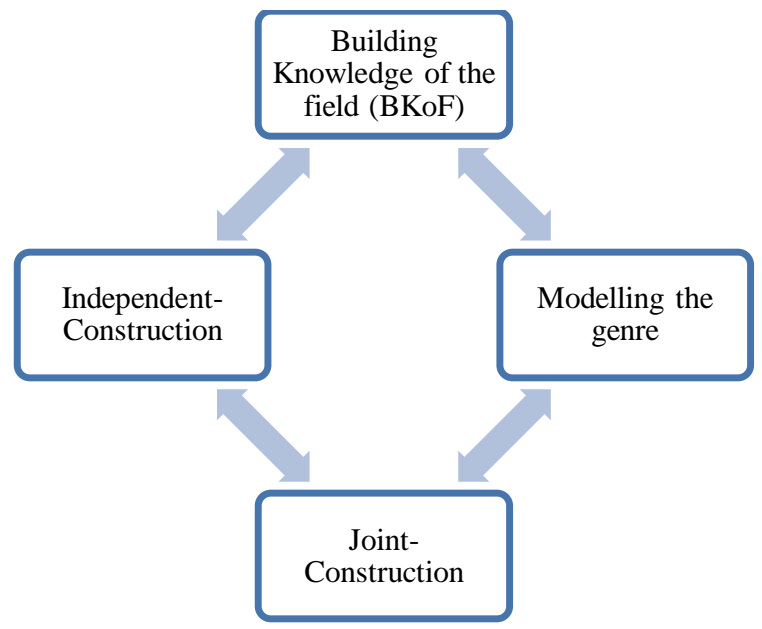

Figure 1. Teaching and Learning Cycle proposed by Derewianka and Jones (2012).

The BKoF phase is closely related to the establishment of students' prior knowledge towards the genre they are focusing on by utilising and integrating multimodal resources and language skills to support the students' learning activities (Derewianka \& Jones, 2012; Emilia, 2011; Gibbons, 2002). Furthermore, Gibbons (2015) suggests that BKoF phase enables the students to learn deeply about the content knowledge as they learn about the topic they are about to produce. This phase is also essential to connect the students' understanding and experience related to a particular genre and the learning topic (Rozimela, 2013). In other words, teachers are encouraged to incorporate multimodal media to allow students to explore relevant materials to the genre being discussed. In addition, teachers are also advised to highlight the linguistic features of the genre discussed.

Modelling phase relates to teaching the knowledge and the processes involved in a genre/text type. In this case, students learn about the social function of the text, as well as the linguistic features and structures which organise the text (Derewianka \& Jones, 2012; Gibbons, 2015). In terms of the pedagogical practice, Gibbons (2015) emphasise the teachers to teach the language resources in the context of language use. In other words, this stage relates to the development of students' awareness of the knowledge of the language, including linguistic features and text structures. Consequently, the teaching of linguistic and schematic structures should also be in accordance with the teaching of content, that is Environmental Change.

In Joint-Construction phase, the students are considered able to comprehend the basic linguistic features and schematic structure of the text type being learned, though the students are still not prepared to compose the text independently (Derewianka \& Jones, 2012). In the classroom, Gibbons (2015) provides an example where the teacher scribes the structure of the text while the students contribute toward the content of the text. Morton (2010): "students and teacher together build a representative example of the genre in question. Throughout this process, teachers and students are jointly building the relevant content that will be packaged in the genre under construction." 
In Independent-Construction phase, the students are asked to work in pairs to apply their understanding towards the genre by composing the text that has been learned individually. Emilia (2011) highlights the common misconceptions perceived by teachers which utilise this stage as a one-go writing test for the students without considering the natural process of composing a text, including drafting, editing/revising, etc.

In the Indonesian context, this teaching approach has become the basis for developing the students' language skills (listening, reading, speaking, and writing) through the inclusion of various text types. In this case, the genre-based approach has been adopted in the 2004 curriculum or Competency-Based Curriculum, 2006 curriculum or School-Based Curriculum, and the 2013 curriculum as the latest curriculum (Nurlaelawati \& Novianti, 2017; Rozimela, 2013). In the classroom context, the genre-based approach has been widely implemented in various educational levels in Indonesia (see Amalia \& Hartono, 2013; Emilia \& Hamied, 2015; Ilham \& Aminullah, 2014; Nurlaelawati \& Novianti, 2017; Yulianti, 2017). These studies generally report the successful implementation of the learning approach to develop the students' language skills in the classroom. Since Coyle (2007) advises practitioners to incorporate CLIL with an established framework of learning and teaching, therefore genre-based approach, as an established framework that has been adopted in the Indonesian curriculum for almost two decades, is considered essential to be embedded in CLIL programs to jointly develop the students' language and content competences.

\section{Correlating CLIL with Genre-Based Pedagogy}

Genre-based pedagogy has been applied in a CLIL context by several researchers in recent times (see Llinares \& Pena, 2015; Lo \& Jeong, 2018; Lorenzo, 2013; Morton, 2010). Regarding its relevance, it is argued that genre-based pedagogy is considered relevant to be utilised in CLIL setting since students are exposed by various types of texts/genres while they are engaging with language and content teaching and learning in different topics/themes (Cendoya \& Bin, 2010). Furthermore, Hyland (2007) adds that, as a pedagogical framework, genre-based pedagogy enables teachers to create a contextualised learning circumstance by combining the dimensions of language, content, and context. In this case, it can be argued that genre pedagogy is able to meet the relevance of 4Cs holistic approach to CLIL proposed by Coyle et al. (2010). This is strengthened by Morton's (2010) argument that genre-based pedagogy enhances the CLIL practices by addressing each dimension of 4Cs approach that will be explored further below.

In relation to 'Content' as the first dimension, genre-based pedagogy promotes an integrated learning activity with careful consideration of the dimensions of language and content. In this case, the meaning is construed in certain social practices, including the learning activities in Science lesson, while language enacts as a pivotal learning tool to make sense of the content (Morton, 2010). Regarding the second C (communication), it is argued that genre-based pedagogy enables teachers and students to engage in communication practices in the form of discourse and language that can also be discovered in the specific academic culture (Morton, 2010). In other 
words, the communication aspects involved in the learning activities are contextually relevant to the specific subject taught to the students, including science/environmental change.

In regard to the third C (cognition), the use of genre pedagogy in CLIL setting enables the students to engage with cognitive processes that resemble the thinking processes that can be discovered in specific subjects (Morton, 2010). In the current unit of work, the students engage with several text types, including multimodal report texts (spoken and written) which allow them to immerse in cognitive processes regarding the environmental change, including the causes and effects, as well as the possible solutions to tackle environmental problems. Ultimately, Morton (2010) argues that genre-based pedagogy enhances the dimension of culture, as the fourth C, by allowing the learners to see the texts engaged in learning activities as a cultural artefact rather than merely a product. Furthermore, Morton (2010) argues that meanings in school subjects can be conceptualised differently by certain cultures in different ways, which create an opportunity to enhance intercultural understanding. In the current unit of work, students will also be exposed with several text types, primarily report texts that inform different cultural practices enacted by certain community groups to tackle environmental change. From that way, the students are expected to be able to enrich their cross-cultural understanding in taking steps to deal with environmental change.

\section{Actualizing CLIL and GBA-based Learning: A Unit of Work}

The current unit of work is inspired by the Teaching and Learning Cycle proposed by Derewianka and Jones (2012; see also Derewianka, 1990, as cited in Gibbons, 2002, 2015) which consists of four different phases, including Building Knowledge of the Field, Modelling, JointConstruction, and Independent-Construction. In the current unit of work, science lesson is selected as the subject with "Climate Change and Waste Recycling" as the core topic. In terms of the curriculum implementation, the unit of work will focus on the use of the 2013 curriculum as the latest curriculum in Indonesia. Additionally, the learning materials used in this unit of work are derived primarily from the Content Standards, which covers the set of information/subjects that the students are expected to learn. In this case, Grade 10 students are expected to learn 'Environmental/Climate Change and Waste Recycling' in Science lesson in semester 1 for 15 learning hours, or approximately seven face-to-face meetings (Standar Isi Pendidikan Dasar dan Menengah, 2016). 
Table 2. The unit of work for BKoF and Modelling phases

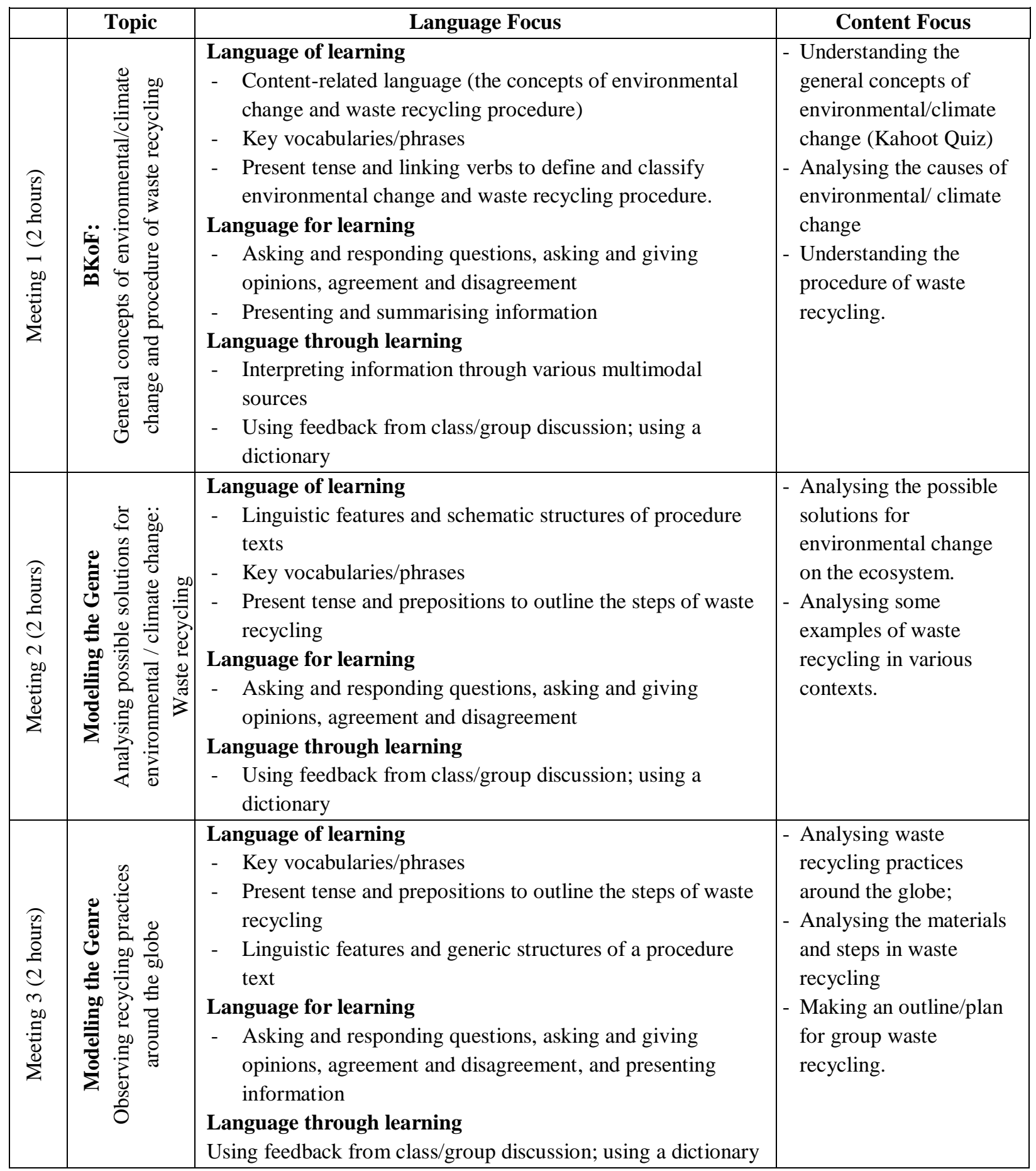

\subsection{Building Knowledge of the Field}

In the unit of work, the initial learning activities in every meeting are aimed at establishing the students' content knowledge regarding environmental change and waste recycling procedure. For instance, the students are asked to engage in a joyful game called Kahoot Quiz to discuss the 
content knowledge and their prior knowledge thoroughly. This is also following the statement by Rozimela (2013) who clarifies that BKoF phase enacts as a connection between the students' prior knowledge and experience in understanding a particular genre and the learning topic. In this case, Kahoot quiz and other warm-up activities can be utilised to connect these two aspects. In addition, students are also engaged in various learning activities, such as watching videos, quiz, discussion, etc. Consequently, the students will possess the body of knowledge that can be essential when they are about to construct a procedure text about waste recycling in the final meeting. During the classroom meeting, the students should also be equipped with language for learning (e.g. asking and responding questions, asking and giving opinions, presenting information) and language through learning (e.g. using feedback from a discussion, using a dictionary) to maximise their learning experiences in the classroom.

\subsection{Modelling}

After BKoF phase, the students are invited to learn about the social function, linguistic features and structures of the texts that will be learned in the content by exposing the students to various models of the texts (Derewianka \& Jones, 2012; Gibbons, 2015). In the current unit of work, Modelling the Genre phase is conducted in two meetings, that is initially started from Meeting 2. In the second meeting, the students are encouraged to build their awareness towards the social functions, the linguistic features, and the schematic structures of the procedure text through numerous activities, including 'shapenoticing', text analysis, grammar and vocabulary exercises (Cloze activities), as well as text reconstruction where the students are asked to rearrange the jumbled text about waste recycling procedures. Furthermore, the students are also given some online materials and articles related to waste recycling strategies conducted in various contexts (national/abroad) to make them aware of the language and content aspects. Additionally, the subsequent meetings also allow the students to engage with other kinds of procedure texts to enrich their understanding of the genre. Regarding this, the students are also invited to prepare for the next stage (Joint construction) by asking them to conduct a group project to perform waste recycling practices.

\subsection{Joint-Construction}

Joint-construction phase is conducted in two meetings in this unit of work. The learning activities in the first meeting allows the students to analyse the materials and procedures of the waste recycling process. In addition, they are also invited to compose an outline/draft of their waste recycling process in the form of a procedure text (draft). After that, they are also asked to discuss their project plan with other groups to check, clarify, and revise the materials and steps that will be conducted during the project. Ultimately, they are invited to present their project plan (in the form of a procedure text) in front of the classroom. The role of the teacher is to facilitate the students in every group when they are collecting the information and constructing it into a procedure text. The rationale for conducting these learning activities is to broaden the opportunities for student-centred learning activities in the classroom. In the subsequent meeting, the students are invited to report and present their group projects about waste recycling practice in front of the classroom. They are encouraged to share the materials and procedures that were conducted during 
the project. In this case, teachers can enact as a facilitator to mediate the discussion between the presenters and the rest of the students. The activities that are conducted in joint-construction phase enact as channels for the students to form a representative example of the text being discussed (procedure text) about waste recycling practice as a way to prepare them for the final phase (Independent construction).

Table 3. The unit of work for Joint and Independent Construction phases

\begin{tabular}{|c|c|c|c|}
\hline & Topic & Language Focus & Content Focus \\
\hline 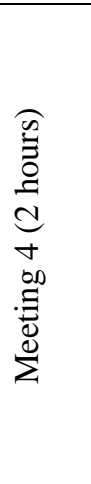 & 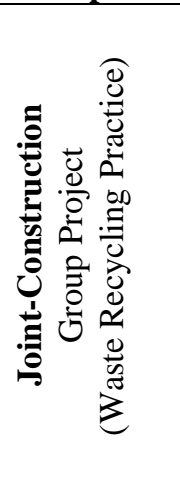 & $\begin{array}{l}\text { Language of learning } \\
\text { - } \quad \text { Key vocabularies/phrases } \\
\text { - } \quad \text { Present tense and prepositions to outline the steps of } \\
\text { waste recycling } \\
\text { - } \quad \text { Linguistic features and generic structures of a procedure } \\
\text { text } \\
\text { Language for learning } \\
\text { - Asking and responding questions, asking and giving } \\
\text { opinions, agreement and disagreement, and presenting } \\
\text { information } \\
\text { Language through learning } \\
\text { - Using feedback from class/group discussion }\end{array}$ & $\begin{array}{l}\text { - Analysing the materials } \\
\text { and steps of a waste } \\
\text { recycling group project. } \\
\text { - Creating a draft of waste } \\
\text { recycling procedure for a } \\
\text { group project. }\end{array}$ \\
\hline 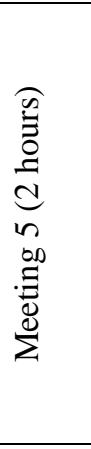 & 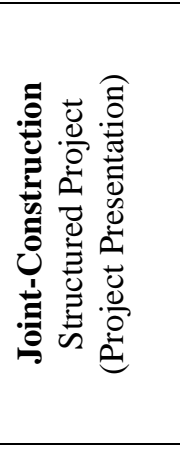 & $\begin{array}{l}\text { Language of learning } \\
\text { - Key vocabularies/phrases } \\
\text { - } \quad \text { Present tense, prepositions, action verbs to construct a } \\
\text { simple procedure text } \\
\text { Language for learning } \\
\text { - Asking and responding questions, asking and giving } \\
\text { opinions, agreement and disagreement, and presenting } \\
\text { information } \\
\text { Language through learning } \\
\text { - Using feedback from class/group discussion; using a } \\
\quad \text { dictionary }\end{array}$ & $\begin{array}{l}\text { - Analysing the materials } \\
\text { and steps of a waste } \\
\text { recycling group project. } \\
\text { - } \quad \text { Reporting and presenting } \\
\text { waste recycling group } \\
\text { project. }\end{array}$ \\
\hline 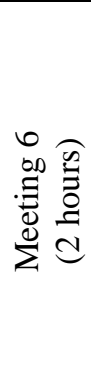 & 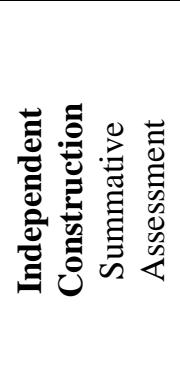 & $\begin{array}{l}\text { Assess language competence related to: } \\
\text { - } \quad \text { Vocabulary related to environmental change (causes and } \\
\text { effects), and waste recycling procedure } \\
\text { - } \quad \text { Technical vocabulary } \\
\text { - } \quad \text { Present tense } \\
\text { - } \quad \text { Adjectives and modality } \\
\text { - } \quad \text { The generic structure of a procedural text }\end{array}$ & $\begin{array}{l}\text { Assess content competence } \\
\text { related to: } \\
\text { - } \quad \text { The causes, and the } \\
\text { impacts of environmental } \\
\text { change on the ecosystem } \\
\text { - Waste recycling } \\
\text { procedure (linguistic } \\
\text { features and generic } \\
\text { structure). }\end{array}$ \\
\hline 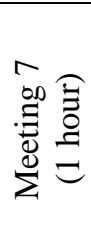 & 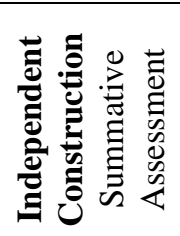 & Final revision of the waste recycling procedure text & $\begin{array}{l}\text { Displaying the students' final } \\
\text { text about 'waste recycling' } \\
\text { on the classroom information } \\
\text { board. }\end{array}$ \\
\hline
\end{tabular}

\subsection{Independent-Construction}

In the unit of work, the sixth and seventh meetings are specifically allocated for the students to engage with the process of writing (collecting information, drafting, self-editing, peer- 
editing/discussion, and publishing). Ultimately, the students are allowed to collect their final draft and display their works on the classroom notice board in the seventh meeting. This is conducted to avoid the misconception of many teachers who use independent-construction phase as a one-go writing test for the students without considering the natural process of composing a text such as drafting, editing, and revising (see Emilia, 2011). Consequently, the students are given opportunities to compose the final text for two meetings in order to facilitate the nature of the writing process for the students.

\section{Conclusion and Recommendation}

In conclusion, there are several concepts that have been explored in this paper. First, the paper has explored the fundamental concepts of Content Language Integrated Learning (CLIL) and Genre-Based Approach (GBA). As an answer for bilingual education emergence in the European context, CLIL is also considered relevant to be used in Indonesia due to several relevancies with the Indonesian context. Meanwhile, GBA is a learning approach that has been implemented for almost two decades in the Indonesian curricula (from the 2004 curriculum to the latest curriculum). Additionally, this paper has also provided a new insight by exploring the underexplored area of incorporating CLIL and GBA in teaching Biology/Science for Senior High School students in Indonesia. In this case, this paper also provides a unit of work to illustrate the practical aspect of incorporating CLIL and GBA to teach waste recycling practice for Senior High School Students in Indonesia.

Regarding the recommendations for future practice, there are three major themes that I would like to outline in this paper. First, collaborations between language and content teachers should be emphasised in order to create a successful CLIL lesson. In this case, both teachers can cooperate to compose the evaluation means for monitoring the students' learning progress. In addition, language and content teachers can also ensure the equal proportion of language and content aspects in a CLIL lesson. Second, since exposure and modelling are considered essential in language learning, content teachers should possess a good command of English, including the understanding of genres/text types, linguistic features, as well as the schematic structures. Ultimately, schools also have vital roles in ensuring the availability of instructional materials, developing both language and content teacher competences, as well as providing additional programs to assist students' English proficiency in maximising the effectiveness of a CLIL lesson.

\section{Acknowledgement}

This study was based on the author's coursework assignment during his master's degree at Monash University. The author would like to acknowledge that all elements in this manuscript have not been published in any primary literature (conference proceedings, journal article, book, and book chapter).

\section{References}

Amalia, R. N., \& Hartono, R. (2013). The integration of genre based approach into scientific approach in When English Rings a Bell to teach recount text. Journal of Chemical 
Information and Modeling, 53(9), 85-92. https://doi.org/10.1017/CBO9781107415324.004 Bentley, K. (2010). The TKT course: CLIL module. Cambridge University Press.

Cendoya, A. M., \& Bin, M. V. Di. (2010). A CLIL experience based on the use of tasks and different genre types. Latin American Journal of Content \& Language Integrated Learning, 3(1), 11-17. https://doi.org/doi: 10.5294/laclil.2010.3.1.2

Coyle, D. (2007). Content and language integrated learning: Towards a connected research agenda for CLIL pedagogies. International Journal of Bilingual Education and Bilingualism, 10(5), 543-562. https://doi.org/10.2167/beb459.0

Coyle, D., Hood, P., \& Marsh, D. (2010). CLIL: Content and language integrated learning. Cambridge University Press.

Dalton-Puffer, Christiane. (2011). Content-and-language integrated learning: From practice to principles? Annual Review of Applied Linguistics, 31, 182-204. https://doi.org/10.1017/S0267190511000092

Derewianka, B., \& Jones, P. (2012). Teaching language in context. Oxford University Press.

Dharmaningtias, D. S. (2013). Penghapusan kebijakan Rintisan Sekolah Berstandar Internasional (RSBI). Politica, 4(2), 263-285. http://jurnal.dpr.go.id/index.php/politica

Education Sector Analytical and Capacity Development Partnership. (2013). Evaluation of international standard schools in Indonesia.

Emilia, E. (2011). Pendekatan genre-based dalam pengajaran Bahasa Inggris: Petunjuk untuk guru. Rizqi Press.

Emilia, E., \& Hamied, F. A. (2015). Systemic Functional Linguistic Genre Pedagogy (SFL GP) in a tertiary EFL writing context in Indonesia. TEFLIN Journal, 26(2), 155. https://doi.org/10.15639/teflinjournal.v26i2/155-182

Gibbons, P. (2002). Scaffolding language, scaffolding learning: Teaching second language learners in the mainstream classroom. Heinemann.

Gibbons, P. (2015). Scaffolding language, scaffolding learning: Teaching second language learners in the mainstream classroom (2nd ed.). Heinemann.

Harmer, J. (2015). The practice of English language teaching. Pearson Education.

Hyland, K. (2007). Genre pedagogy: Language, literacy and L2 writing instruction. Journal of Second Language Writing, 16(3), 148-164. https://doi.org/10.1016/j.jslw.2007.07.005

Ilham, I., \& Aminullah, A. (2014). The implementation of genre based approach in teaching discussion text. Paedagoria, 9(1), 52-65.

Ioannou Georgiou, S. (2012). Reviewing the puzzle of CLIL. ELT Journal, 66(4), 495-504. https://doi.org/10.1093/elt/ccs047

Lasagabaster, D., \& Sierra, J. M. (2009). Immersion and CLIL in English: More differences than similarities. ELT Journal, 64(4), 367-375. https://doi.org/10.1093/elt/ccp082

Llinares, A., \& Pena, I. P. (2015). A genre approach to the effect of academic questions on CLIL students' language production. Language and Education, 29(1), 15-30. https://doi.org/10.1080/09500782.2014.924964

Lo, Y. Y., \& Jeong, H. (2018). Impact of genre-based pedagogy on students' academic literacy 
development in Content and Language Integrated Learning (CLIL). Linguistics and Education, 47, 36-46. https://doi.org/10.1016/j.linged.2018.08.001

Lorenzo, F. (2013). Genre-based curricula: Multilingual academic literacy in content and language integrated learning. International Journal of Bilingual Education and Bilingualism, 16(3), 375-388. https://doi.org/10.1080/13670050.2013.777391

Mehisto, P., Marsh, D., \& Frigols, M. J. (2008). Uncovering CLIL: Content and Language Integrated Learning in bilingual and multilingual education. Macmillan.

Morton, T. (2010). Using a genre-based approach to integrating content and language in CLIL: The example of secondary history. In C Dalton-Puffer, N. Tarja, \& S. Ute (Eds.), Language use and language learning in CLIL classrooms (pp. 81-104). John Benjamins Publishing Company.

Nurlaelawati, I., \& Novianti, N. (2017). The practice of genre-based pedagogy in Indonesian schools: A case of preservice teachers in Bandung, West Java Province. Indonesian Journal of Applied Linguistics, 7(1), 160-166. https://doi.org/10.17509/ijal.v7i1.6869

Rose, D., \& Martin, J. R. (2012). Learning to write, reading to learn: Genre knowledge and pedagogy in the Sydney school. Equinox.

Rozimela, Y. (2013). Reaching the goal of ELT in Indonesia through understanding the competency and genre-based teaching. Proceedings of National Seminar on English Language Teaching, 49-59.

Yulianti, E. (2017). Genre based approach in teaching writing analytical exposition text. Jurnal Pendidikan Progresif, 7(1), 47-54. https://doi.org/10.23960/jpp.v7.i1.201706

Yuliantoro, D. A. (2016). Rintisan sekolah bertaraf Internasional (RSBI) court case and contesting visions of Indonesian national identity. ProQuest. 